by arranging, as the Brundrott Committee recommonded, for the work on extraction of metals and that on mineral processing to be integrated under the samo rosearch direction.

\section{The Council for National Academic Awards}

IN a written reply on July 2 to a question by Mr. Julian Critchley, Mr. Hogg announced the membership of the new Council for National Academic Awards under the chairmanship of Sir Harold Roxbee Cox (Nature, 201, 975; 1964): The Viscount Caldecote (deputy chairman, English Electric); Mr. W. F. Cartwright (managing director, Steel Co. of Wales); Mr. Michael Clapham (director of Imperial Chemical Industries); Sir James Cook (vice-chancellor, University of Exeter); Mr. B. Downs (head of Department of Mechanical Engineering, Loughborough College of Advanced Technology); Miss Helen L. Gardner (reader in English literature, University of Oxford); Dr. D. E. R. Godfrey (head of Mathematics Department, Woolwich Polytechnic); Mr. H. N. Henry (principal, Paisley College of Technology); Prof. J. Lamb (professor of electrical engineering, Univorsity of Glesgow); Mr. J. Russell Lang (chairman, G. and J. Weir, Ltd., Glasgow); Dr. Kathleen Ollerenshaw (Manchester City Councillor and member of Manchester Education Committe®); Dr. O. G. Pickard (principal, Ealing Tөchnical Colloge); Sir Arnold Plant (professor of commerce, University of London); Mr. R. H. J. Rhodes (viceprincipal, Leds College of Commerce); Prof. G. D. Rochestor (professor of physics, University of Durham); Sir Lionel Russell (chief education officer, Birmingham); Dr. J. Topping (principal, Brunel College of Advanced Technology); Mr. D. Vitkovitch (head of Electrical Engineering Department, Nottingham and District Technical Colloge); Dr. G. E. Watts (principal, Brighton College of Technology); Mr. R. E. Wood (principal, Leicester College of Technology and Commerce); Dr. E. G. Woodroofe (joint vice-chairman, Unilevor). The new Council will take over the responsibilities of the National Council for Technological Awards as soon as it is in a position to do so, but the latter will continue to administer the Diploma in Technology in the meantime.

\section{The Commonwealth Development Corporation}

The annual report of the Commonwealth Development Corporation for the year ended December 31, 1963, welcomes the Commonwealth Development Act, 1963, which became law in July 1963 (Pp. vi + 102. London: H.M.S.O., 1964. 6s. 6d. net). The Act restored the Corporation's full powers of oporation in all those countries within the Commonwealth which had achieved independence sineo the Corporation was ostablished in 1948. The Corporation's area of activity had becn contracting year by year and, now that tho area of investment has boen restored to that of 1948 , it should again be possible to expand the volume of investmont. The useful future of increasing activity now foreseen should be beneficial in sustaining the essential morale of the staff, which in some territories overseas had faced a year of danger with a steadiness to which the roport pays tribute. Ton now projects involving a total commitment of $£ 6,585,000$ wero approved during the year; three large projects involving $£ 3,400,000$ are in independent Commonwealth countrios. Plans for further investment in existing projects have been approved for a total of $£ 3,860,000$; howovor, these figuros do not give full weight to new projects approved by local dovolopmont companies in which the Corporation has an interest. The falling away of now project approvals in 1962 was reflected in a further contraction of new invostmont from $£ 9.5$ million in 1962 to $£ 6.8$ million in 1963 , but the whole of this new investment was financed from sources other than additional drawings from the Treasury, to which there was a net repayment of $£ 100,000$, in addition to the $£ 629,000$ formula payment in reduction of frozen balances. The operating surplus of $£ 4,751,622$ was
$£ 391,000$ greater than in 1962 , but the present arrangemonts do not give sufficient margin against the commercial and other risks that the Corporation is bound to run; the operating margin continues to narrow. Besides loans for public utility (infra-structure) purposes and investments in large-scale agricultural, industrial and estate projects, the Corporation's investment is increasingly directed to projects involving association with and support of the peoples of the countries in which it operates. Recently, a particular aim has been to make available to small farmers some of the benefits of present-day scientific advances in growing, handling and processing tropical erops.

\section{Qualifications in Biology}

THE Institute of Biology has agreed to join with the professional institutes for othor sciences and the Ministry of Education in a schome for an Ordinary National Certificate in the Sciences. This will replace the Ordinary Endorsed Certificate in Biology and Ordinary National Cortificate in Chemistry and Physics. Those intending to proceod to a Higher National Certificato in Appliod Biology will study biology to a higher level than mathematies, physies and chemistry. It is likely that, of the time available for scientific subjects, one-half will be available for biology, one-quarter for chemistry and onequarter for mathematics and physies. The Institute is represented on the Joint Committeo for the Ordinary National Certificato in the Sciences by Prof. C. G. C. Chesters and Dr. R. J. Terry. The Committee will later issue rules and notos for guidance with the view of courses commencing in September 1965. Tho Instituto has also been considering means of admitting persons to membership of the Institute as a result of an examination set by the Institute. It is envisaged that tho examination will be taken after three years part-time study by persons who enter the course with a Higher National Certificate in Applied Biology. Thero would be a Part 1 examination at the end of the first year, at which candidates would take papers in the principles of biology and in a special subject. The Part 2 examination would bo on the special subject alone. The subjects at presont being considered aro biochemistry, entomology, mierobiology, pharmacology and plant pathology. For these subjects, panols aro preparing syllabusos. A mooting was recontly held with representatives of technical colleges and of the major omployers of biologists at which comments wero roceived on the schome. A proliminary enquiry shows that somo twonty colleges hope to be able to offor coursos with a total intake of some 150 studonts. Coursos loading to the examination for membership of the Institute of Biology will commence in Soptember 1965.

\section{The Macaulay Institute for Soil Research}

THE thirty-third annual report of the Macaulay Institute for Soil Research for 1962-63 summarizes the work in progress and includes a list of seventy papers, published or submitted for publication (Pp. 56. Craigiebuckler, Aberdoen: The Macaulay Institute for Soil Research, 1964). The primary aim of the research continues to be the addition to fundamentel knowledge of soils and soil : plant relationships supported by investigations directed towards the maintenance or improvement of soil fertility. Of the wide range of investigations described, only a short selection is needed to indicate the nature of the activities in the various departments. Electron microscopy and diffraction have been added to the methods for soil mineralogy investigation; pollen analyses of peat deposits are intended to supplement scanty records of vegetational history, and the physical properties of peat to help in investigations of tree growth. The soil survey has completed a further 580 square miles on the $2 \cdot 5$-in. scale, and another memoir (Country Round Aberdeen, Inverurie and Fraserburgh) has been published. Emphasis is laid on the need for moro information on the trace 